Nadiia Kuzmenko, Dr of Sci. (Pedagogy), Prof. Kyrylo Tulin, PhD Stud.

Taras Shevchenko National University of Kyiv, Kyiv, Ukraine

\title{
FUNCTIONING OF HIGHER EDUCATION INSTITUTIONS OF ROMANIA IN THE CONDITIONS OF AUTONOMIZATION
}

The article is devoted to the analysis of the higher education system of Romania. Peculiarities of functioning of higher education institutions of different forms of ownership in the conditions of autonomy are determined. The Romanian practical experience of supporting students educational and professional orientation and promoting their professional inclusion in the labour market is noteworthy. The activities of advisory departments in each institution of higher education regarding students choice of a professional route should be borrowed from Ukraine.

Keywords: autonomy, higher education, higher education institutions, national minorities, Romania.

Introduction. Solving the complex issues of integrating national education into the world civilisation requires study, analysis, involvement, creative interpretation and updating the experience of countries that began adapting educational systems to the modern European model much earlier and have already achieved some success. Studying the knowledge of the higher education system in Eastern Europe, in particular, Romania, can be helpful for Ukraine primarily because of the similarity of educational changes that are taking place in Ukraine today and have already taken place in neighbouring Romania. The analysis of positive tendencies will improve the autonomy of Ukrainian universities, and the study of negative tendencies will save from mistakes in the development of the quality assurance system of university education.

Analysis of recent research and publications. The problems of the functioning of the Romanian higher education system are, to some extent, represented in the scientific research of foreign (R. Lucu and L. Todorescu, A. Strat, R. Danchiu) researchers. Ukrainian researcher M. Oliynyk made a historical and pedagogical analysis of the stages of formation of the system of teacher training in Eastern Europe, focusing on the experience of Poland and Romania. I. Mariutz analysed the stages of reforming Romania's higher education. M. Palchuk paid attention to studying the functioning of vocational education and training in Romania. However, in the conditions of socio-economic changes and constant improvement of the higher education system, there is a need for a deeper analysis of the functioning of higher education institutions in the conditions of autonomy.

The purpose of the article is an in-depth analysis of the functioning of the Romanian higher education system in the context of the autonomy of higher education institutions.

Presentation of main positions. By the provisions of the Law on National Education №1/2011, universities and other higher education institutions in Romania have autonomy and have the right to establish and implement their development policy within the legal framework established by current legislation. The Ministry of National Education coordinates the activities of universities and other higher education institutions while respecting the autonomy of universities.

The university's autonomy is correlated with the principle of personal and public responsibility for the quality of all didactic and scientific activities carried out in higher education institutions. The university's autonomy covers management, structuring and operation of the institution, didactic and research activities, administration and financing. From a financial point of view, the university's autonomy is realised as the right to manage funds allocated from the state budget or other sources, according to the Law and the personal responsibility of higher education institutions. State higher education is financed from the state budget based on funding agreements between the Ministry of Education, Research, Youth and Sports and higher education institutions [Cotoi, Sulea, \& Cotoi, 2012].

The national education system in Romania is open. At the level of higher education, openness is ensured by the Charter of a different university. The Charter of the university is adopted by the Senate of the university and establishes a set of rights and responsibilities, as well as the rules governing the activities of the university community in each field. Higher education is provided by the following types of higher education institutions: universities, institutes, educational academies, whose mission might include education and research or education only.

The specialisations and groups of specialisations are established by the Ministry of National Education and the Ministry of Labour, Social Solidarity and Family, higher education institutions, and other stakeholders. Higher education institutions, as a rule, structurally have several faculties, colleges, departments and divisions of research, design and micro-production. Training indicators for all educational levels, financed from the state budget and local budgets, are set annually by government decisions [Strat \& Danciu, 2013].

According to the Law on National Education №1/2011, only high school graduates with a bachelor's degree can be enrolled in higher education institutions. Higher education institutions establish the admission methodology by the general criteria established by the Ministry of National Education. The selection and admission procedure can be based on the average obtained by candidates from the bachelor's exam and various disciplines studied in high school and the grade obtained in the entrance exam, entirely organised by higher education institutions.

Candidates for the bachelor's degree are high school graduates. For candidates who have received honours in secondary school competitions and competitions recognised by the Ministry of National Education and international, higher education institutions may provide their methods and applicable Law special requirements for admission, except for the possibility of enrolment without entrance competition places financed from the budget. This provision can be used only once by current legislation [LEGE Nr. 1/2011, 2020].

According to the Romanian Law №441/2001 "On Approval of the Government Emergency Order №133/2000 "On State and Postgraduate Public Education with Payment", higher education institutions have the right to accept a certain number of students, which exceeds the number of places financed from the state budget, for conditions that students agree to pay tuition fees. Candidates accepted for paid positions must exceed the minimum limit set in the admission criteria [Mariuts, 2012]. 
For the entire study period, students receive free medical and psychological care in university medical and psychological offices or clinics and departments of public hospitals. They also enjoy a $50 \%$ discount during the year on the cost of domestic public transport (except air transport) and tickets to museums, concerts, theatre, opera, cinema, and other cultural and sporting events organised by government agencies. Orphan students have the right to use free domestic transport (except air transport). For other levels of education, scholarships and other forms of material and financial support are provided according to specific criteria [Tulin, 2020].

From the 2005-2006 academic year, all higher education institutions, public or private, were required to implement a new education structure at three levels: bachelor, master and doctor. First-year students began studying in a new structure. The official provisions for the new structure apply to all institutions (accredited or authorised to operate temporarily), industries and specialisations, except for professions regulated at the level of the European Union. Each level has its admission and releases procedures [Mariuts, 2016].

Within the Romanian higher education system, special rules have been set for studying conditions applicable to regulated professions at the European level. The first level, a bachelor's degree, includes a minimum of 180 and a maximum of 240 credits, depending on the field and specialisation. The second level, the master's degree, includes a minimum of 60 and a maximum of 120 study credits depending on the duration of the first level, provided that the total number of credits for the I and II levels is at least 300 [Romiţă \& Liliana-Luminiţa, 2012].

Current Romanian legislation provides the general framework necessary for establishing private educational institutions of all levels, including universities and other higher education institutions. To be recognised as part of the national education system, private educational institutions must be accredited by the procedures established by Law. The establishment of public or private higher education institutions is possible only with the help of special laws by the procedure of accreditation and recognition of diplomas of higher education institutions. Diplomas and certificates issued by accredited private educational institutions provide the same benefits as diplomas issued by public educational institutions. The responsibility for the administration and financing of the activities of private educational institutions rests entirely with the organisers of such private institutions.

Representatives of national minorities have the right to study and study in their mother tongue at all levels and in all forms of education, provided there is sufficient demand. Therefore, the conditions for teaching in the languages of national minorities for students belonging to these minorities are organised in several higher education institutions. Besides, some higher education institutions have organised initial teacher training departments for teaching minority languages in pre-university education. Simultaneously, the Law on National Education № 1/2011 stipulates that learning Romanian as the state language is a duty for all citizens, regardless of nationality [Cotoi, Sulea, \& Cotoi, 2012].

Higher education institutions form a curriculum for each field of activity and specialisation recognised by the Romanian Law GD 493/2013. The curriculum is a complex document that includes the duration of the study, subjects by type and year of study, activities, number of hours allocated for subjects and activities, loans, etc.

Curricula are established independently of higher education institutions by national higher education development strategies and national academic standards. According to the Law on Accreditation of Higher Education Institutions and Recognition of Diplomas (88/1993), the higher education program must include compulsory, optional and optional subjects. Compulsory and optional subjects should belong to one of the following categories: fundamental disciplines, profile or specialised disciplines and additional disciplines [Tulin, 2020].

The structure and content of the curriculum in terms of subjects, activities and number of hours must comply with national academic standards. Specific standards establish an indicative list of essential, specialised (specialised) and additional disciplines and their weight limits in the curriculum for each specialisation. Depending on the specialisation, the share of different types of disciplines in the total number of hours can be $15-30 \%$ for basic disciplines, from $50 \%$ to $80 \%$ for specialised (specialised) disciplines and between $5 \%$ and $10 \%$ for additional disciplines. Most training programs are compulsory (at least $60 \%$, but up to $90 \%$ for specific specialisations). Electives may be eligible for credit, but this is not usually practised. In terms of activity, national standards established for each field of reference and specialisation the relationship between theoretical activity (courses) and practical (seminars, laboratories, practical training, project activities, etc.). For most specialisations, this ratio is $1: 1$ with a maximum deviation of $20 \%$ in either direction; however, for specific specialisations, the time allotted for practical activities should be much longer than the time allotted for theoretical classes (for example, 1:2 in the case of medicine).

The final curriculum for each discipline is developed by higher education institutions by these specific standards, analysed by the councils of departments and approved by the Senate of a particular university. Modern language courses are required, regardless of field or specialisation. Many educational institutions provide full training in a modern language of international use for specific specialisations [Palchuk, 2011].

Educational and methodological activities must meet the requirements established by national academic standards in terms of basic types and duration allocated to each area of activity and specialisation. Teaching activities include courses for most disciplines (academic activities), seminars, laboratory, practical activities and project preparation. Courses are usually conducted with many students and provide basic knowledge in a particular field of study. The seminars are dedicated to the in-depth study of the topics presented in the courses and require the active participation of students. Laboratory hours conducted with smaller groups of students are devoted to research and practical classes conducted under the supervision of a teacher. Specific specialisations require practical activities, such as fieldwork, research, teaching practice, and so on. Teachers have complete freedom in choosing teaching methods. During the teaching activities, teachers use a variety of teaching methods by the specifics of specialisation and discipline, including:

- methods based on exposure (description, explanation, etc.) and methods based on conversation (conversation, heuristic conversation, problem-solving, etc.) - especially during classes;

- methods of teaching and research by discovery: direct research of objects and phenomena (systematic and independent observations, experiments, practical activities, etc.) and indirect research (problem-solving, demonstration with images, films, etc.) - especially during seminars, laboratory work and practical measures;

- project preparation and presentation [Romiţă \& Liliana-Luminiţa, 2012]. 
The teaching materials used in higher education depend on specialisation and discipline. Computer training is widely used for modelling, design, data processing, presentations, information and data collection, communication and more. In higher education institutions and many campuses in Romania, students have unlimited access to public computers connected to the Internet.

Assessment of students in higher education institutions is carried out through periodic (final) exams organised for each discipline in the curriculum. Assessment takes the form of oral, written and practical tests and, in some cases, project presentations. Higher education institutions set criteria for evaluating students' academic and professional results in accordance with university autonomy. Specific requirements and evaluation criteria for each discipline are set out in the introductory part of the file of each discipline [Radkevych, 2018]. Assessment of students success in higher education is based on grades from 1 to 10 . The exam of students in each discipline is taken by a commission consisting of a teacher who supports the courses of the discipline and at least one other specialist from the same department or faculty. After each exam, the grades given to students are recorded in student records and in official documents of the institution.

Higher education institutions hold two regular examination sessions during the academic year - usually in February and June-July, respectively - and at least one re-examination session, which is usually held in the autumn, before the start of the academic year. Re-examinations are organised for students who have not passed at all or have not passed one or more subjects during regular examination sessions. Students have the opportunity to try three times to make a particular discipline; students who do not pass the discipline after these three tests must retake all the training activities organised for that discipline. According to the provisions of the legislation, higher education institutions may set specific financial fees for re-examination [Romiţă \& Liliana-Luminiţa, 2012].

Students who have not passed the exam twice in a particular subject may be transferred to the next year and may retake the exam with the Rector's approval. This third test must be completed by the first regular examination session this year. Students who do not pass the exam for the third time must complete all educational activities organised in the relevant discipline for the second time.

Completing long-term higher education ends with an exam organised based on general criteria established by the Ministry of National Education. The content of the exam and specific criteria are set by the university senates within their autonomy. Graduates who have passed the bachelor's exam receive the title of bachelor in the relevant profile and specialisation, certified by a diploma issued by the institution organising the exam. Graduates who do not pass the exam can receive on request a certificate of long-term university education and a copy of the transcript - indicating all the subjects studied and grades obtained.

Students or graduates who choose the teaching profession must complete courses organised by the Department of Teaching Staff (DPPD). Passing these special training courses is certified by a diploma [Romiţă \& Liliana-Luminiţa, 2012]. Final exams must be taken before an examination board created for each specialisation to obtain higher education. Examination commissions are created by the Rector of the institution of higher education, which organises the exams based on the proposals of the faculty councils. The examination commission must have at least three members with the title of doctor. The chairman of the commission must perform the didactic function of a professor or associate pro- fessor of the university. The diploma supplement was introduced based on a Ministerial Order adopted in April 2000. Today, it is issued automatically and free of charge for higher education programs in Romanian and English by all higher education institutions.

To support the educational and professional orientation of students and promote their professional inclusion in the labour market, each higher education institution has established advisory departments on the choice of professional route and presence in the labour market. Maintaining constant contact with the labour market, departments have the following general functions:

- provide stakeholders with information on existing industries and curricula in higher education;

- provide students with information and advice on choosing or changing an individual career path in the context of the university program and credit-module system;

- encourage the establishment of alumni associations of higher education institutions that support both its interests and the interests of new generations of graduates with economic, cultural and administrative communities at the local or regional level;

- constantly study the needs of the labour market and promote specific measures for knowledge of companies and their needs in academically qualified personnel;

- provide consulting, methodological and pedagogical support in student learning, maintaining contact with the economic and business environment [Romiţă \& Liliana-Luminiţa, 2012].

The doctoral diploma is the highest scientific degree awarded in all fields, after 3-4 years of study and original research. It is awarded based on the first academic degree (or master's degree) and requires examinations and the submission of an original dissertation. The holder of a doctoral degree receives a doctorate in this field (doctor of sciences or arts). According to the current legislation, a doctoral degree is provided in sciences and arts in fundamental areas. In science, the doctoral degree is organised in the following fields: exact sciences, natural sciences, humanities, social and political sciences, educational sciences, economics, legal sciences, agricultural and forestry sciences, medical sciences, architecture and urban planning, engineering sciences, theology, military sciences. In the arts, the fields in which the doctoral degree is organised are visual arts, music, theatre, cinema, ballet, physical education and sports. Completion of doctoral studies is characterised by the development and defence of a doctoral dissertation and the appointment of a doctoral degree.

According to the Law on National Education № 1/2011, doctoral programs are usually organised in the form of fulltime education and, except in the form of part-time employment. The content of doctoral studies includes the following:

- general training in a high-level doctoral school in the form of courses or seminars:

- the training course, determined by the student and the supervisor, and then approved by the council of the department or the academic council of the research institute;

- public presentation of the doctoral dissertation [Romiţă \& Liliana-Luminiţa, 2012].

Conclusions. Thus, the analysis of the functioning of Romanian higher education institutions allows us to conclude that Romanian legislation in the field of education provides equal access to all levels of higher education for both Romanian citizens and national minorities, carefully regulate educational processes, taking into account the authentic learning opportunities of participants educational process. The conditions for the autonomy of higher education institutions provide 
more guarantees for improving the higher education system. The study of the Romanian experience of the functioning of higher education institutions in the conditions of autonomy can be helpful during the reform of the educational system of Ukraine with the aim of its qualitative renewal and integration into the European educational space.

\section{References}

Mariuts, I. O. (2012). Etapy reformuvannia vyshchoi osvity Rumunii. Aktualni problemy sotsiolohii, psykholohii, pedahohiky, 15, 206-212.

Mariuts I. Perspektyvy rozvytku universytetskoi osvity Ukrainy iz zastosuvanniam dosvidu Rumunii / I. Mariuts // Visnyk Kyivskoho natsionalnoho universytetu imeni Tarasa Shevchenka. Pedahohika. - 2016. - № 1(3). - S.45-48.

Palchuk M. Model profesiinoi osvity y navchannia v Rumunii - piatyi etap yevropeiskoi intehratsii / M. Palchuk // Nauk. visn. Mykolaivskoho derzh. un-tu imeni V.O. Sukhomlynskoho. Seriia: Pedahohichni nauky. - 2011. Vyp. 133. - S.169-175.

Suchasni modeli profesiinoi osvity i navchannia v krainakh Yevropeiskoho Soiuzu: porivnialnyi dosvid: monohrafiia / V.O. Radkevych / za zah. red. V. O. Radkevych. - K.: IPTO NAPN Ukrainy, 2018. - 343 s.

\section{Надія Кузьменко, д-р пед. наук, проф.}

Кирило Тулін, асп.

Київський національний університет імені Тараса Шевченка, Київ, Україна

\section{ФУНКЦІОНУВАННЯ ЗАКЛАДІВ ВИЩОЇ ОСВІТИ РУМУНІЇ В УМОВАХ АВТОНОМІЗАЦІї}

Проаналізовано системи вищої освіти Румунії та особливості функціонування закладів вищої освіти різних форм власності в умовах автономізації. Досліджено основні нормативно-правові документи, які регулюють функціонування системи освіти Румунії, зокрема закон "Про національну освіту", №1/2011 від 5 січня 2011 р. Визначено, що відповідно до Закону "Про національну освіту" університети та інші заклади вищої освіти Румунії мають автономію і відповідно право встановлювати та реалізовувати власну політику розвитку заідно з чинним законодавством. У свою чергу, Міністерство національної освіти координує діяльність університетів та іниих закладів вищої освіти, дотримуючись автономії університетів. Розелянуто особливості функціонування закладів вищої освіти на різних освітніх рівнях: бакалаврському, магістерському, докторському. Визначено встановлені спеціальні норми заклади вищої освіти Румунії щодо умов навчання до регульованих професій на європейському рівні. Бакалаврський рівень включає мінімум 180 і максимум 240 кредитів залежно від галузі та спеціалізації. Магістерський рівень включає мінімум 60 і максимум 120 навчальних кредитів залежно від тривалості першого рівня. Розглянуто особливості діяльності учасників освітнього процесу закладів вищої освіти Румунії. Особливу увагу приділено діагностиці знань і умінь студентів та організації екзаменаційної сесії, випускних іспитів та можливості перескладання. Студенти або випускники, які обирають професію викладача, зобов'язані закінчити курси, організовані кафедрами для підготовки викладацького складу (DPPD). Заслуговує на увагу румунський практичний досвід підтримки освітньої та професійної орієнтації студентів і сприяння їхнього професійного долучення до ринку праці. Проаналізовано загальні функції та діяльність консультативних відділів щодо вибору професійного напряму студентами, що варто запозичити Україні.

Ключові слова: автономізація, вища освіта, заклади вищої освіти, національні меншини, Румунія.
Tulin K. Zakonodavchyi vymir funktsionuvannia systemy osvity Rumunii / Visnyk Kyivskoho natsionalnoho universytetu imeni Tarasa

Strat, V. A., \& Danciu, A. R. (2013). The higher education system in Sciences: 3 rd World Conference on Learning, Teaching and Educational eadership, 93, $859-863$. (he Romanian higher education system from the proctive of the Bologna process. Practical application for Technical Higher ORLD 2011, 33, 1008-1012.

Romania. Present and perspective. Procedia - Social and Behavioral Sciences, 46, $1096-1100$

Отримано 2021, 3 https://edu.ro/sites/default/files/_fi \%C8 \%99iere/Legislatie/

Надійшла до редколегії 20.03.21 